\title{
Putting Pragmatism to Work in the Cold War: Science, Technology, and Politics in the Writings of James B. Conant*
}

\author{
Justin Biddle ${ }^{+}$
}

\begin{abstract}
This paper examines James Conant's pragmatic theory of science - a theory that has been neglected by most commentators on the history of $20^{\text {th }}$-century philosophy of science - and it argues that this theory occupied an important place in Conant's strategic thinking about the Cold War. Conant drew upon his wartime science policy work, the history of science, and Quine's epistemological holism to argue that there is no strict distinction between science and technology, that there is no such thing as "the scientific method," and that theories are better interpreted as policies rather than creeds. An important consequence that he drew from these arguments is that science is both a thoroughly value-laden, and an intrinsically social, enterprise. These results led him to develop novel proposals for reorganizing scientific and technological research - proposals that he believed could help to win the Cold War. Interestingly, the Cold War had a different impact upon Conant's thinking than it did upon many other theorists of science in postwar America. Instead of leading him to "the icy slopes of logic," it led him to develop a socially- and politically-engaged theory that was explicitly in the service of the American Cold War effort.
\end{abstract}

\section{Introduction}

Thanks to recent work of scholars in the history of the philosophy of science, we now have a much better appreciation of the political engagement of the philosophy of science community in America in the years leading up to the height of the Cold War. As a result of this work, we have a much better understanding of early- and mid-twentieth-century debates over the role of values and interests in science (Howard, 2003), and we have a persuasive explanation for why these debates largely disappeared in the second half of the twentieth century. George Reisch (2005) has argued convincingly that the Red Scare of the late 1940s and early 1950s affected the American philosophy of science community profoundly, the result of which was a shift away from questions of social and political importance and toward more abstract and socially-disengaged issues - that is, toward “the icy slopes of logic.”1

\footnotetext{
* I am indebted to many for their comments on this paper, especially to Don Howard, who directed the dissertation out of which the paper arose. I have also benefited from the comments of Paul Baer, Matt Brown, Martin Carrier, Nancy Cartwright, Kevin Elliott, Chris Hamlin, Michael Hoffmann, Bryan Norton, Alan Richardson, Robert Rosenberger, and two anonymous reviewers.

+ To contact the author, please write to: School of Public Policy, Georgia Institute of Technology, 685 Cherry Street, Atlanta, Georgia 30332; email: justin.biddle@pubpolicy.gatech.edu

${ }^{1}$ The phrase "to the icy slopes of logic," which is the subtitle of Reisch’s 2005 book, is taken from
} 
The Cold War, however, did not have this effect upon all theorists of science. The aim of this paper is to examine an important yet neglected theorist of science, one who developed a sophisticated account of the role of values and interests in science and of the relationship between science, technology, and democracy, and who did so explicitly in service of the American Cold War effort against the Soviet Union. James Bryant Conant is well known as a former president of Harvard University, an influential science policy advisor during WWII and in the beginning of the Cold War, and a commentator on American education; his philosophical writings on science, however, are largely ignored. ${ }^{2}$ In addition to being an influential mentor to Thomas Kuhn, Conant developed a pragmatic theory of science that drew significantly upon the work of John Dewey and the epistemological holism of his Harvard colleague, W.V.O. Quine. Furthermore, Conant discussed in some detail the challenges that the increasing intertwining of science and politics posed for both science and democracy, and he drew upon his theory of science in order to propose corresponding changes in the organization of scientific and technological research. These organizational changes, he argued, would facilitate scientific and technological progress - something that was important not only for its own sake, but for the ideological and possible military battles that the U.S. would wage against the Soviet Union.

Conant's theory of science, and the ideological uses to which it was put, cannot be understood outside of the context of his wartime science policy work and his work in science education. These topics are discussed in Sections 2.1 and 2.2. The next sections proceed to an analysis of his theory of science. Conant's science policy work led him to propose a pragmatic account of the relationship between science and technology, according to which there is no sharp distinction between the two (Section 3.1). Section 3.2 discusses his rejection of "the

Carnap et al. (1996 [1929], p. 339). As both Reisch and an anonymous reviewer point out, not all philosophy of science in the 1950s was socially and politically disengaged (e.g., Rudner (1953)). However, the studies of both Howard (2003) and Reisch (2005) confirm that the extent of social and political engagement in the 1950s was far less than it had been earlier in the century.

${ }^{2}$ One exception to this is Fuller (2000). His primary aim is to examine Conant's influence on the Thomas Kuhn; my aim is a very different one. 
scientific method" - understood in the sense of an algorithmic method by which theories can be generated univocally from data. This argument, in part because of its reliance upon the history of science, anticipates one of the major themes of Kuhn's Structure of Scientific Revolutions (Kuhn, 1962). Conant’s argument also draws explicitly upon Quine’s epistemological holism, which he uses to support his belief that the "activities of scientists in their laboratories are shot through with value judgments” (Conant, 1952, p. 107). His acceptance of Quine’s epistemological holism serves additionally as background to his view on the nature of scientific theories (Section 3.3). Influenced by Dewey's The Quest for Certainty (Dewey, 1929), Conant argues that theories are "policies, not creeds;” that is, they are not attempts to represent the natural world with ever-increasing accuracy but rather are guides to action that help us to navigate our environments in increasingly effective ways.

Finally, I discuss two of the ways in which Conant put his theory of science to work. Conant's epistemological holism and his belief that scientific and technological research is "shot through with value judgments" led him to argue that science is an intrinsically social enterprise. As a result, Conant thought deeply about the institutional structure of scientific research and how these structures can be improved. Conant's work in the Manhattan Project gave him a first-hand look at science operating in secret, and while he believed that such secrecy was necessary during the war, he nonetheless argued that "secrecy and science are fundamentally antithetic propositions” (Conant, 1952, p. 31). His position on secrecy and science, which is the subject of Section 4.1, led him to worry deeply about the progress of postwar nuclear research and the ability of a democratic society to make informed decisions about such research. Finally, in Section 4.2, I discuss a novel proposal for organizing scientific and technological research, one that Conant believed would solve many of the problems that arise in secret science: a system of "quasi-judicial review.” As we will see, Conant's proposals for reorganizing scientific and technological research were significant not 
only epistemically, but also politically, as he believed that they were crucial to winning the Cold War.

\subsection{Conant as Wartime Science Advisor ${ }^{3}$}

Conant lived most of his adult life either working at, or writing on, the intersection of science, technology, and politics; much of his work was on weapons development. After receiving a bachelor’s degree and a Ph.D. in chemistry from Harvard in 1914 and 1916, respectively, he spent a year during WWI in the research division of the chemical warfare service. After the war, he returned to Harvard to teach chemistry, and in 1933 he was elected President of Harvard, a position that he retained until 1953, when President Eisenhower appointed him U.S. Ambassador to West Germany. During WWII, he continued to work to harness science for weapons development, providing both technical and policy advice. One of the spheres in which Conant was particularly influential was in helping to build scientific institutions that drew systemically upon the country's growing scientific expertise for the development of innovative weapons technologies.

In 1940, at the urging of Conant's friend and colleague, Vannevar Bush, President Franklin D. Roosevelt established the National Defense Research Committee (NDRC), which aimed at "stimulating, extending and correlating fundamental research which is basic to modern warfare” (Bush, quoted in Zachary, 1997, p. 109). In 1941, the Office of Scientific Research and Development (OSRD) - a more powerful executive agency charged with overseeing the use of science for military purposes - was formed. NDRC, along with the newly formed Committee on Medical Research, became subsidiaries of OSRD (Hershberg, 1993, p. 147; Zachary, 1997, pp. 129-130). Conant chaired NDRC between 1941 and 1946 he was described in an official history of the committee as "perhaps the most influential

\footnotetext{
${ }^{3}$ For biographical details, I have relied upon Hershberg (1993), Conant (1970), and Zachary (1997).
} 
NDRC member” (Hershberg, 1993, p. 147) - and was second in charge, behind Bush, of OSRD. $^{4}$

During this time, Conant was influential in helping to oversee the development of the atomic bomb. In 1941, he became the chair of the Executive Committee of OSRD’s S-1 section, which was charged with the initial stages developing the bomb. The committee oversaw such crucial tasks as determining the feasibility of a self-sustaining fission reaction and the various methods for acquiring sufficient amounts of enriched uranium (U-235) (Conant, 1970, pp. 283-285; Hershberg, 1993, pp. 147-148). Conant in particular provided influential technical advice regarding the feasibility of various programs and methods. Because Bush was busy with political maneuvering - “advocating the cause of military science in the Washington corridors" - he did not have the time to keep up with the technical aspects of the bomb project (Hershberg, 1993, p. 148). For this task, Bush relied heavily on Conant; his memos to Bush “on technical matters, administration, and policy determined the contents of most of Bush's atomic reports to the president until late in the war” (Hershberg, 1993, p. 148). Authority over the bomb project was transferred in 1942 from the civilian OSRD to the military; from that point, the Military Policy Committee (MPC) oversaw the project. The MPC served as a consultation board for General Leslie R. Groves, the head of the Manhattan Project; Bush chaired the committee, which also included representatives from the army and the navy. Conant was an alternate to Bush, and he attended and participated in all of the committee’s meetings (Hershberg, 1993, p. 161). One of Conant’s primary tasks on the MPC was to serve as a liaison between the scientists working on the bomb and the military officials overseeing the project (Conant, 1970, p. 291).

In addition to helping to build the bomb, Conant also advised on its use. He served on the Interim Committee, a committee established by President Truman in May 1945, which was mandated to study and report on both the wartime and postwar control of atomic research

\footnotetext{
${ }^{4}$ Further discussions of Conant's work in NDRC and the Office of Scientific Research and Development (OSRD) can be found in Kevles (1978).
} 
(Hershberg, 1993, p. 224). The committee did not seriously address the question of whether the bomb should be dropped; its usage during WWII was, for the most part, a foregone conclusion. Of special concern to the committee were the questions of where the bomb should be dropped, whether any advanced warning should be given, and whether the United States should attempt to establish international control over atomic weapons after the war. Conant argued that the bomb should be dropped on Japan without any advanced warning and that the United States should pursue the option of postwar international control over atomic weapons. These two beliefs, moreover, were not unconnected. Conant believed that the psychological shock that would result from an atomic attack on Japan would not only lead to that country's early surrender, thus sparing the lives of thousands of American soldiers; he also believed wrongly, as it turned out - that it would provide leverage with the Soviet Union in securing genuine postwar cooperation. In their September 30, 1944 memo to Secretary of War Henry Stimson, Bush and Conant acknowledged that the sharing of military secrets "would presumably be violently opposed in this country as well as Russia since it would mean in the last analysis the opening of all industrial plants to officials of an international organization;” however, such sharing might be accepted, they argued, "if people in this country and in other countries are convinced of the terrific potentialities of the new weapons which now lie just over the horizon” (quoted in Hershberg, 1993, p. 219). The Interim Committee eventually agreed with the view of Conant and Bush that the U.S. should take early steps toward ensuring international cooperation; in particular, the committee recommended to Truman that he inform Stalin in Potsdam of the existence of a new, revolutionary means of warfare and that, if pressed for details, he set up future discussions regarding international control (Hershberg, 1993, 230). Aside from a casual comment to Stalin regarding a new weapon, however, Truman made no serious attempt to initiate such discussions. ${ }^{5}$

\footnotetext{
${ }^{5}$ Given the information that Klaus Fuchs had been providing, Stalin was already well aware of the American bomb project (Rhodes, 1986).
} 


\subsection{Science Education in the Cold War}

Conant's wartime science policy work was intimately connected with another of his passions: public education, and science education more specifically. Indeed, Conant's educational philosophy was, for him, an essential part of winning the Cold War (Slaney, 2005). The Cold War, in his view, would not be decided through:

brute force matching brute force [but rather by] competing for the allegiance of the dispossessed of the world, the ill-fed underdog. We both promise that our way of life means increased prosperity and greater personal happiness for the wretched peoples of this planet. (quoted in Hershberg, 1993, p. 402)

Public education, Conant argued in the late 1940s, was crucial to the future of America because "our survival depends on a vigorous demonstration in the next decade that we can make our form of democracy function even in a war-torn world” (quoted in Hershberg, 1993, p. 403).

One of Conant's more well-known educational initiatives was the inauguration of the Harvard undergraduate course, Natural Sciences 4: “On Understanding Science.” Given the increasingly significant role that science was playing in politics, both domestic and international, and given the consequent impact that science was having on the lives of average citizens, Conant argued that it is essential that the public have an adequate understanding of science:

Whether we like it or not, we are all immersed in an age in which the products of scientific inquiries confront us at every turn. We may hate them, shudder at the thought of them, embrace them when they bring relief from pain or snatch from death a person whom we love, but the one thing no one can do is banish them. Therefore every American citizen in the second half of this century would be well advised to try to understand both science and the scientists as best he can. (Conant, 1951, p. 3)

General education, however, was failing to provide students with such an understanding. In his capacity as a member of NRDC and OSRD, he witnessed "the bewilderment of lawyers, business men, writers, public servants (and not to mention a few Army and Navy officers) when confronted with matters of policy involving scientific matters” (Conant, quoted in 
Hershberg, 1993, p. 409). As a result, Conant made it a goal of Harvard's general education program to provide all students with an understanding of science.

Natural Sciences 4 was a means of attaining this goal. The emphasis of the course was not so much on the content of science as on the activity of science, including the various processes according to which scientists make decisions about which projects to undertake and which hypotheses to accept. He wanted to provide students with "an appreciation of how scientific research is really done... the difference between controlled and uncontrolled observation and experiment; the difference between basic research and applied research; and the relation of both to development and production” (Conant, quoted in Hershberg, 1993, p. 409). One of the primary texts for the course was the two-volume Harvard Case Histories in Experimental Science (Conant, 1957), which contains detailed case studies of important developments in the history of science, such as Boyle’s experiments in pneumatics, the chemical revolution and the overthrow of the phlogiston theory, and the development of the atomic-molecular theory. The case studies focus, again, not simply on the results of scientific endeavors but on the long and sometimes torturous routes to obtaining these results. By acquainting laypeople with the various forms of experimentation and reasoning employed in these episodes, Conant hoped to provide citizens with the tools to follow scientific debates to the degree required by a well-functioning democracy. ${ }^{6}$

Both Conant's work as a wartime science policy advisor and an educational theorist had a significant impact upon his pragmatic theory of science and technology. In particular, there are three crucial aspects of his theory that I will discuss in Section 3: the entanglement of science, technology, and politics; epistemological holism and the lack of an algorithmic scientific method, and the nature of scientific theories.

\footnotetext{
${ }^{6}$ Providing the educated citizen with an understanding of science was not only a goal of Natural Sciences 4, but also a goal of many of Conant's speeches and writings after WWII. Three of his books - On Understanding Science (1947), Science and Common Sense (1951), and Modern Science and Modern Man (1952), and his essay, "Science and Politics in the Twentieth Century (1950)," all had such a focus.
} 


\subsection{On the Relation between Science and Technology}

One of the central lessons that Conant drew from his experience in the Manhattan Project was the growing entanglement of science, technology, and politics. This entanglement, he argued, provides important insights into the nature of science and technology, and it poses new and perplexing challenges to democratic societies.

In a number of his writings and lectures - in particular, his Bampton lectures of 1952, which are reproduced in his Modern Science and Modern Man (Conant, 1952) - Conant told a now-familiar story regarding the development of science and technology. For much of the modern period, technological development resulted primarily from the work of "inventors" engaged in trial and error reasoning; during this time, science and technology seemingly developed independently of one another. This began to change in the late nineteenth century, particularly in Germany, when chemical and electrical industries began to employ scientists and to take advantage of scientific advances for technological development. Connections were forged with German universities, and graduate training in these universities expanded in order to supply highly trained scientists to industry. Yet, while some governments and industries in the late nineteenth century started to understand the importance of science for technological development, this understanding was sporadic and incomplete. The American public and many parts of the American government still viewed scientists as ivory tower thinkers who could contribute little to technological change. As an illustration of this attitude, Conant related the story of President Woodrow Wilson appointing a board during WWI to consult with the Navy on weapons development. In a move hailed by the public, Thomas Edison was chosen to chair the board. Only one physicist sat on the board. "The solitary physicist... owed his appointment to the fact that Edison in choosing his fellow board members had said to the President, 'We might have one mathematical fellow in case we have to calculate something out'” (Conant, 1952, p. 18). As a scientist working on chemical weapons development in 
WWI, and as an administrator working with both scientists and the military brass in WWII, Conant experienced such attitudes first hand (Conant, 1970).

The image of scientists as impractical theorists changed dramatically in WWII, Conant observed, in particular with the creation and explosion of the atomic bombs (Conant, 1952, p. 20). After the dropping of the bombs:

The transition was complete; the scientist was no longer thought of as a man in an ivory tower, gradually unraveling the secrets of nature for his own spiritual satisfaction, but as a miracle-worker who like Watt or Edison before him could bring about tremendous transformations of man's relation to his material surroundings. (Conant, 1952, p. 21)

Conant argued that one of the most important factors behind this shift in the perception of scientists was that in the Manhattan Project, the development of science and technology were very clearly interwoven with one another. The development of the atomic bomb was not simply an application of previously worked-out science. In this respect, the bomb was different from the development of chemical weapons in WWI, as in that case, the chemistry behind these weapons was well understood ahead of time; the development of the weapons themselves did not represent a scientific advance of any sort, merely an application of it (Conant, 1952, p. 23). In the case of the atomic bomb, however, the development of the sciences related to nuclear processes and the development of the technological capacity to wage nuclear warfare were advanced in tandem; neither without the other would have been sufficient.

To me, the fact of prime importance is this: in the period 1940 to 1945 a whole army of specialists was engaged in advancing science in a spectacular fashion and at the same time was developing a new weapon of great military power. This combined activity was a new social phenomenon; we are still struggling with its consequences. (Conant, 1952, p. 22)

The Manhattan Project, thus, represented a striking illustration of the fact that the development of science and technology are inextricably intertwined.

This narrative of the entwining of science and technology illustrates a central component of Conant's pragmatic theory of science, namely, that theory and practice are not 
different in kind, but are rather related to one another intimately. Conant's science policy experience in WWII represented, for him, one argument for this view. The development of the atomic bomb was neither the first nor the only example of the interrelatedness of science and technology, theory and practice; indeed, it is a general feature of science and technology that they cannot be distinguished sharply from one another. But the bomb provided a striking illustration of the entanglement of science and technology, one that had important implications for Conant's theory of science. In Section 3.3, we will see another of Conant's arguments for the interconnection between theory and practice, one that derives from a discussion of the nature of scientific theories. Similar to Dewey and other pragmatists, Conant rejected the notion that science aims to develop theories that represent the world accurately, while technology aims to apply those theories to intervene in the world in reliable ways. Before proceeding to that, however, we must examine Conant's epistemological holism.

\subsection{Epistemological Holism and "the Scientific Method"}

Perhaps the most central feature of Conant's theory of science is his argument that there is no such thing as the scientific method. This argument, Conant maintained, is important not only for theorists of science, but for the general public as well. "It would be my thesis that those historians of science, and I might add philosophers as well, who emphasize that there is no such thing as the scientific method are doing a public service” (Conant, 1952, p. 35). What did Conant mean by “the scientific method”? While he discussed a number of different formulations of this supposed method, he maintained that any would involve the following two claims: (1) there is a single procedure, or set of rules, that scientists follow (or should follow), and (2) following this procedure will ensure that inquiry is dispassionate and unprejudiced. Neither of these claims, he argued, is true.

His argument against both of these claims depends upon a form of epistemological holism. Experiments, he argued in Duhemian fashion, never test individual hypotheses in 
isolation but rather test complexes of hypotheses and auxiliary assumptions; if an expected experimental result is not observed, we must attempt to determine, without the benefit of any algorithm or set of rules, which statements within the complex of hypotheses and auxiliary assumptions should be abandoned. ${ }^{7}$ To illustrate this point, he discussed the well-known 1648 experiment by Pascal and Perier to test Torricelli's hypothesis of atmospheric pressure (Conant, 1951, pp. 69-76). Torricelli hypothesized that the earth is surrounded by a "sea of air” and that this air has weight. Pascal argued that if Torricelli's hypothesis is correct - i.e., if we really are surrounded by a "sea of air" that exerts a pressure on us that is analogous to the pressure that water exerts on submerged objects - then objects at lower altitudes should be subject to greater pressures than objects at high altitudes, just as objects far beneath the surface of the ocean are subject to greater pressures than objects near the surface. To test this, he arranged for his brother-in-law, Perier, to carry out a series of experiments on a mountain in France, the Puy-de-Dôme. Perier measured the height of mercury at different altitudes on the mountain; as expected, he found that the height of mercury was highest at the bottom of the mountain, and that the height gradually declined as he ascended the mountain. This experiment, Conant argued, illustrates nicely the view that theories can only be confirmed as wholes, because the observation that the height of the barometer declines as one ascends in altitude only supports the hypothesis in question given a barrage of auxiliary assumptions.

For all Pascal or Perier knew, a mercury column might be appreciably shorter at the top of a mountain than below for a variety of reasons: the relative densities of mercury and air might change (the ideas about gravity were then in the process of formulation); the measuring stick might alter in length on being moved upward several thousand feet. Perier himself recognized that an open space and an enclosed building might make a difference, also a passing cloud. (Conant, 1951, p. 76)

Given the holistic character of theory testing, as evidenced by examples such as this, Conant concluded that scientific reasoning cannot be understood in terms of an algorithmic method.

\footnotetext{
${ }^{7}$ For Duhem’s view on this issue, see Duhem (1954 [1906], Chapter 6).
} 
By this time, of course, the epistemological holism that we find in Conant's work was not new; it had been defended, in one form or another, by Pierre Duhem (1906), Otto Neurath (1913), Philipp Frank (1954), Quine (1951), and others. While the extent to which Conant was familiar with these individuals is not completely clear, there is strong evidence that he had at least some acquaintance with all of them. Quine and Frank were both at Harvard at the same time as Conant. ${ }^{8}$ Frank taught in the Harvard general education program, the program in which Conant's course, Natural Sciences 4, was offered. Conant provided a welcome address to the Fifth International Congress for the Unity of Science in 1939, which was organized by Frank, Neurath, and others (Science Dec. 2, 1938; Hershberg, 1993, p. 411). Furthermore, the language that Conant employed to describe his holism, especially his usage of the phrase “auxiliary assumptions” (e.g., Conant, 1951, p. 53), strongly suggests a familiarity with the writings of Duhem.

Regarding Quine, it would be hard to believe that they were not personally acquainted, given the fact that he and Conant spent so many years together at Harvard. In any case, Conant made very clear in his Eddington Memorial Lecture of 1967, entitled Scientific Principles and Moral Conduct, that he was familiar with Quine’s writings. In that lecture, he quoted Quine’s discussion of underdetermination as representing his own views:

Let me extend my original definition of science. I shall be bold enough to wrap the mantle of an eminent American logician around me. I present a quotation or two from Professor W. V. Quine's book From a Logical Point of View. Under the heading "Empiricism Without Dogmas" he writes as follows:

The totality of our so-called knowledge or beliefs, from the most casual matters of geography and history to the profoundest laws of atomic physics or even of pure mathematics and logic, is a man-made fabric which impinges on experience only along the edges. Or, to change the figure, total science is like a field of force whose boundary conditions are experience. A conflict with

\footnotetext{
${ }^{8}$ An anonymous reviewer has asked about the relationship between Conant's theory of science and Frank's - and, more generally, about the place of Conant's theory in the broader discussion in the 1950s over the role of values in science. This broader debate is discussed in Reisch (2005, Chapters 11, 14). In many respects, Conant's and Frank's theories are similar, especially in that both develop underdeterminationist arguments in favor of an ineliminable role for values in science. This is in contrast to another argument for values in science prominent at that time: Rudner's argument from inductive risk (Rudner, 1953). There is certainly more to be said regarding the relationship between Conant, Frank, and other participants in the 1950s science and values debate; doing so, however, must await another occasion.
} 
experience at the periphery occasions readjustments in the interior of the field. (Quoted in Conant, 1967, p. 12) $^{9}$

Conant continued by asserting that one of the essential features of Quine’s philosophy, namely the view that "our statements about the external world face the tribunal of sense experience not individually but only as a corporate body,” is also essential to his own view of science (Quine, quoted in Conant, 1967, p. 13).

In addition to employing Quine’s epistemological holism to argue that hypothesis acceptance (and rejection) is not a rule-governed activity, Conant also drew upon Quine’s holism to argue against the view that scientific reasoning can be dispassionate and unprejudiced. The underdetermined character of theory choice, in conjunction with what we know about the way in which scientists actually reason, demonstrates that "activities of scientists in their laboratories are shot through with value judgments” (Conant, 1952, p. 107). He continued:

There is a fairly common fallacy that if you are dealing with scientific and technical matters, judgment of values rarely, if ever, enters in. Facts speak for themselves in science, we are often told. Anyone who is familiar with the course of scientific research and development knows this is nonsense. What is true is that the area of debate is fairly definitely circumscribed. (Conant, 1952, p. 113)

Elsewhere, Conant suggested that the circumscribed character of debates over values is the primary reason why many people believe that scientific reasoning can be value-free. Yet, while the operation of value judgments is, in many cases, difficult to discern, it becomes particularly visible in periods of revolution, or in conflicts between what he calls competing “conceptual schemes.” In a passage highly suggestive of Kuhn’s later writings, Conant wrote:

A well-established conceptual scheme blocks for a time the acceptance of a new one; the conservative defenders of the old theory attempt to patch it up. Sometimes, as in the case of the phlogiston theory, the result is only a delaying action. The significant point to be noted is the way that both sides, in a controversy of this sort, put aside experimental evidence that doesn't fit into their scheme. And what is most significant, subsequent history may show that such arbitrary dismissal of "the truth" was quite justified. (Conant, 1951, p. 189)

\footnotetext{
${ }^{9}$ This quotation is from Quine (1951, p. 39).
} 
While Conant did not use the terms "incommensurability" or "paradigm" to describe this phenomenon, he described the clash of “conceptual schemes” in a way that bears obvious resemblance to Kuhn’s discussion of scientific revolutions (Kuhn, 1962, Chapter IX). In such conflicts, Conant argued, it is clear that scientists do not look upon the world in a direct, unprejudiced way; rather, they examine the world in a decidedly interested fashion.

Though Conant was clear in his belief that scientific reasoning is shot through with value judgments, he was not explicit about the precise nature of these value judgments. Since the late 1970s and early 1980s, it has become common to distinguish between "epistemic values” and "non-epistemic values" - where, on most interpretations, epistemic values are truth conducive and non-epistemic are not - and to argue that only epistemic values legitimately influence hypothesis acceptance in science (e.g., McMullin, 1983). Quine himself made an argument similar to this (Quine and Ullian, 1970, Chapter 5), which reflects his steadfast reluctance to question the fact/value distinction. While Conant never considered explicitly the possibility of screening out all "non-epistemic values” from the acceptance of hypotheses, it is clear that he would have rejected this move, as included among the "values" that he believes invariably influence scientific reasoning are "biases” and “prejudices” (see Section 4.2 for further discussion). In this respect, it is interesting to note that, in rejecting the fact/value distinction, Conant took Quine’s holism further than Quine himself did. ${ }^{10}$ While Quine accepted many of the radical implications of his holism, he nevertheless remained committed to distinguishing sharply between facts and values (e.g., Quine, 1986). To many of Quine’s more recent commentators, this was a significant shortcoming in his own view (Nelson, 1996; White, 1986); it was one of the few times that Quine failed to recognize the implications of his holism. Conant, as of one year following the publication of Quine’s “Two Dogmas of Empiricism,” had no such difficulty in recognizing this implication.

\footnotetext{
${ }^{10}$ My thinking on this issue has benefited greatly from Norton (2011).
} 


\subsection{Scientific Theories: Policies, Not Creeds}

Conant’s epistemological holism not only led him to reject the fact/value distinction; it also influenced his account of the nature of scientific theories. Conant argued that theories are better viewed as policies rather than creeds. ${ }^{11}$ His usage of the terms "policy” and "creed” comes from the physicist J. J. Thomson, whom Conant quoted as follows:

From the point of view of the physicist, a theory of matter is a policy rather than a creed; its object is to connect or coordinate apparently diverse phenomena and above all to suggest, stimulate, and direct experiment. (Quoted in Conant, 1952, p. 91)

According to Conant, those who view theories as creeds believe that scientific theories aim to represent the world, as it exists independently of us, with ever-increasing accuracy, and that this aim is achievable. On this view, the epistemic aim of science is to produce true (or approximately true) descriptions of the natural world, and when scientific theories are successful (and they sometimes are), we are justified in believing that we are achieving this aim. Conant does not specify precisely what constitutes a "successful” scientific theory, but it involves both predictive accuracy and fruitfulness (Conant, 1957, p. x). In terms of the more recent debate over scientific realism, to view scientific theories as creeds is, at least roughly, to adopt a realist approach to science similar to that defended by Boyd (1983), Psillos (1999), and others.

Conant describes those who view theories as creeds as thinking of their work as analogous to the mapmaking of fifteenth- and sixteenth-century explorers who were seeking an accurate geography. While such explorers might have legitimately thought of their endeavors as yielding representations that increasingly approximated their intended objects, Conant argued that the same cannot be said of scientists:

To my mind, the analogy between the map maker and the scientist is false. A scientific theory is not even the first approximation to a map; it is not a creed; it is a policy - an economic and fruitful guide to action by scientific investigators. (Conant, 1952, p. 97)

\footnotetext{
${ }^{11}$ Recently, Bas van Fraassen (2002) has defended the view that theories should be interpreted as policies rather than as creeds. In many respects, his argument is similar to Conant's.
} 
What, more specifically, did Conant mean by viewing scientific theories as policies? In order to draw out some of the implications of this view, it is helpful to examine some of his reasons against viewing theories as creeds.

The first reason concerns his epistemological holism. On most interpretations, an acceptance of the thesis of underdetermination is incompatible with standard versions of scientific realism, such as, roughly, the view that scientific theories are creeds. Conant drew an explicit connection between his epistemological holism and his view of theories via another quotation from Quine:

As an empiricist I continue to think of the conceptual scheme of science as a tool, ultimately, for predicting future experience in the light of past experience. Physical objects are conceptually imported into the situation as convenient intermediaries - not by definition in terms of experience, but simply as irreducible posits comparable, epistemologically, to the gods of Homer. For my part I do, qua lay physicist, believe in the physical objects and not in Homer's gods; and I consider it a scientific error to believe otherwise. But in point of epistemological footing the physical objects and the gods differ only in degree and not in kind. Both sorts of entities enter our conception only as cultural posits. The myth of physical objects is epistemologically superior to most in that it has proved more efficacious than other myths as a device for working a manageable structure into the flux of experience. ... Science is a continuation of common sense, and it continues the common-sense expedient of swelling ontology to simplify theory. (Quine, 1951, p. 44; quoted in Conant, 1967, p. 15)

On this view, we have no justification for believing that the "conceptual scheme of science" accurately represents a mind-independent reality, only that it provides us with a powerful tool for predicting the future and, more generally, for managing the "flux of experience."

Conant also criticized the theories-as-creeds view by drawing upon the history of recent physics. In an argument that prefigures Larry Laudan’s pessimistic meta-induction, Conant argued that recent physics has undergone a series of revolutions, such that the kinds of entities and structures that were thought to make up the world in the mid-twentieth century are completely different from those postulated in the late nineteenth century (Laudan, 1981). We have little reason to expect that no further revolutions will occur, and as a result, we should be skeptical of those who claim that recent science, and recent physics in particular, provides an accurate or nearly accurate representation of reality. 
Additionally, Conant argued that the recent history of physics implies that a strict separation between theory and practice is untenable - which, if true, would undercut the view that recent physical theories are best viewed as creeds. Conant noted that the Heisenberg uncertainty principle implies that objects do not possess properties independently of the context in which they are measured; rather, the properties possessed by particles depend upon a measurement context. For example, if one chooses to measure one set of variables, the "particles” being measured will be wavelike; if one chooses to measure a different set of variables, the "particles” in question will be particle-like. Summarizing his view, Conant wrote:
A mass of experimental evidence in the twentieth century has provided powerful ammunition to those who look upon a scientific theory as a policy and has made untenable at least one theory regarded as a creed. A policy suggests always a guide to action, and of the various interpretations of science that are current today, those seem to me to be the most useful that emphasize the dynamic nature of science. There are philosophers, I realize, who draw a sharp line between knowing and doing and look askance at all philosophizing that seems to tie the search for truth in any way to practical undertakings. But for me, at least, any analysis of the process of testing a statement made in a scientific context leads at once to a series of actions. (Conant, 1952, pp. 91-92)

Conant's argument that the history of recent physics undermines a strict theory/practice distinction is one of the many places in which Conant's debt to Dewey becomes apparent. Dewey's primary argument in his book The Quest for Certainty is his rejection of "the spectator theory of knowledge,” according to which subjects, or knowers, stand apart from the objects of investigation, acquiring knowledge of them in a passive way (Dewey, 1929). According to this view, states of affairs can be represented accurately without intervening in them, or at least without intervening in such a way as to change them. The spectator theory involves a number of dichotomies that have been central to much of the Western philosophical tradition, including between subject and object, theory and practice, and facts and values. Dewey presents a number of different arguments against the spectator theory, ranging from critiques of the correspondence theory of truth to discussions of the 
epistemological implications of the Heisenberg uncertainty principle, similar to the one mentioned above. Given the strong similarities between the argument of Dewey's The Quest for Certainty and Conant's work, it is not surprising to see Conant make the following obvious allusion to Dewey:

The validity of a new idea and the significance of a new experimental finding are to be measured by the consequences - consequences in terms of other ideas and other experiments. Thus conceived, science is not a quest for certainty; it is rather a quest which is successful only to the degree that it is continuous. (Conant, 1951, pp. 25-26, emphasis added)

On this view, science is not a purely epistemic enterprise - where "purely epistemic" is meant to exclude all practical considerations. Rather, practical considerations are inextricably intertwined with scientific theorizing.

To view theories as policies is to recognize both the failure of the realist aim of developing theories that ultimately converge upon the one true account of the natural world and the inevitability of a practical dimension to scientific theorizing. Conant's epistemological holism implies that our best scientific theories could develop along a number of different paths. Moreover, our theories develop along the paths that they do because of, in part, our own practical interests - interests that influence not only which problems we address, but also the aims, methodological norms and assumptions, and background beliefs that are partly constitutive of research. The inevitable practical dimension to scientific theorizing explains Conant's endorsement of Quine’s claim that physical objects are “cultural posits” that differ only in degree, and not in kind, from the gods of Homer. It also serves as important background to Conant's definition of science as “a series of concepts or conceptual schemes arising out of experiment and observation and leading to new experiments and new observations” (Conant, 1957, p. x). Science, on Conant's view, is a guide to intelligent action; it is the systematic attempt to make coherent sense out of our experience in ways that will enable us to act in desired ways. 
Thus far, we have seen Conant draw upon the history of science and a form of epistemological holism in order to argue for the value-laden character of scientific inquiry and for the view of theories as policies and not creeds. As a committed pragmatist, however, he did not develop his theory merely for its own sake. He also drew explicit practical implications from his theory - in particular concerning the organization of scientific and technological research - which he believed to be crucial to winning the Cold War.

\subsection{Behind a Curtain of Secrecy}

One of the general lessons that Conant drew from his theory of science is that progress in science and technology requires, at a very deep level, effective ways of organizing this research. Of course, it is trivial to maintain that scientific and technological progress requires, as a matter of practice, effective organizational arrangements; progress would obviously be slowed in the absence of, for example, institutions that facilitate the communication of scientific results. But for Conant, the connection between science and social institutions goes deeper. His pragmatic theory of science, and in particular his epistemological holism, led him to argue that particular social arrangements are necessary, in principle, for progress in science and technology. Two necessary features of adequate social arrangements for science and technology are the promotion of openness and the promotion of dissent.

Given the advent of the Cold War, Conant believed that developments in weapons technologies were necessary for U.S. national security. It was widely believed that U.S. national security could not be maintained by funding science only during periods of conflict; the funding of science, in particular science concerned with the development of weapons, would become a permanent priority. The contract system initiated by Bush and Conant in NDRC, according to which the U.S. government contracted with university scientists to perform research related to weapons development, remained in place during the postwar years, continuing the radical restructuring of the relationship between science and the U.S. 
federal government. While Conant supported this contract system during the war years, he opposed the contracting of weapons research to universities during peacetime (Hershberg, 1993). One of his primary reasons for this concerned the increased secrecy brought about by this relationship. Conant worried that the increased secrecy associated with research on weapons development (in particular, with nuclear research) posed problems both for the development of scientific knowledge and for democratic decision-making.

Concerning the epistemic point, Conant argued that the free exchange of ideas is a prerequisite for good scientific research; to the extent that research into atomic processes is not open to the scrutiny of scientific communities, research will likely be compromised epistemically. “Advances in science are difficult within a secret national monopoly because necessarily its research is guarded from all but a few branches of government. Secrecy and science are fundamentally antithetic propositions” (Conant, 1952, p. 31). Similarly, he wrote,

The close relation of some new knowledge in atomic physics to the production of weapons makes it now necessary to introduce a highly disturbing reservation into the story of the growth of rapid and uncensored publication of findings.... There can be no doubt that secrecy is basically incompatible with scientific progress. (Conant, 1951, pp. 22, 332)

Notice here that Conant is not merely arguing that secrecy slows the growth of science, or that secrecy makes scientific progress more difficult to achieve. Rather, his statement that secrecy and scientific progress are "basically incompatible” suggests the view that the free exchange of ideas is a necessary condition for progress in science.

Conant's primary reason for believing secrecy to impede the progress of science is that progress in science requires competition, freedom of thought, and freedom of expression.

Concerning the importance of competition in science, he wrote:

It is conceivable that for certain reasons, unconnected with technological factors, it may be necessary to have monopoly in a given field (either privately controlled and financed, or governmental).... With such a monopoly, however, the problem of stimulating the research and the development groups by some kind of technological competition becomes especially acute. And technological competition is as essential for vigor in science and technology as in any other phase of human endeavor. (Conant, 1951, p. 311) 
His views regarding the relationship between scientific knowledge, on the one hand, and competition, freedom thought, and freedom of expression, on the other, are also evident in his discussions of science in the Soviet Union (Conant, 1950; Conant, 1951, pp. 346-353). Research in the Soviet Union failed to meet the standards of adequate science, on his view, because of the Soviet requirement that theories cohere with the philosophy of dialectical materialism:

When one version of this philosophy is transformed into the official doctrine of a party which must harbor no dissenters, the freedom of scientific thought automatically disappears. This is not to say that within wide limits scientific inquiries may not be ardently supported and that technology may not flourish. But can there ever be genuine scientific freedom in a society where all philosophical opinions must conform to the official interpretation of party dogma? (Conant, 1951, p. 351)

Clearly, he believed not. In his discussion of the international character of science in his Science and Common Sense (1951), he asked if the phenomenon of Soviet science should lead us to cease to view science as an international enterprise. He responded by affirming the international character of science while, at the same time, denying Soviet scientists any status within the worldwide scientific community. "For the time being, we must reluctantly place the scientists on the other side of the Iron Curtain in a special category; unlike the rest of us they do not see in science an activity which knows no national boundaries” (Conant, 1951, p. 353). A paragraph later, he ends his Science and Common Sense with the following statement: “Therefore, whatever any other nation may do, whatever the tension of the times, we must continue to foster science; and that means fostering freedom of inquiry, of discussion, and of publication” (Conant, 1951, p. 353).

Conant's epistemological worries regarding secrecy in science have an obvious political dimension. Like Robert K. Merton shortly before him, Conant maintained that science can only exist in political contexts that allow competition, freedom of thought, and freedom of expression (Merton 1938; 1942). To some extent, Conant’s view functions as a Cold War argument for the superiority of Western democracy. In addition, however, it serves 
as a cautionary note to American citizens: secrecy in science can be detrimental to democracy.

When a science such as nuclear physics is classified, it becomes impossible to have an open, public debate about policies that are based upon that science. In such a policy arena, those with the expertise to comment upon the feasibility and the potential costs and benefits of certain courses of action cannot, because of secrecy restrictions, contribute to a public debate. Conant summed up the situation regarding nuclear power as of 1952 with the following grim assessment:

I can underline what I have been saying by making one bold statement based on twelve years of experience behind the veil of secrecy: It is impossible today or in the foreseeable future to have a frank, rational, searching discussion of the industrial uses of atomic energy. The general public might just as well stop reading anything in the papers about atomic energy or atomic bombs. By the nature of the case it is almost certain to be misleading. (Conant, 1952, pp. 28-29)

Thus, totalitarian countries such as the Soviet Union are not the only countries that face difficulties arising from limits upon freedom of expression; the United States, Conant warned, faces its own difficulties.

At the time of his writing, Conant did not believe that such secrecy restrictions in the United States should be lifted. The Cold War, he argued, necessitates a certain amount of secrecy. “There is no use in wringing one’s hands about the situation.... The world being what it is today and is likely to be for a long time to come, secrecy and applied nuclear physics are words that must be joined together” (Conant, 1952, p. 30). Nevertheless, he argued that the potential deleterious consequences of such secrecy require that the public be aware of the situation and that secrecy restrictions not extend far beyond the realm of nuclear physics.

While Conant's discussion of secrecy in science makes clear his belief that the social organization of science is epistemically significant, he did not, in his discussion of secrecy, explain as clearly as he might have his justification for this belief. This justification, which 
concerns his rejection of the fact/value distinction, becomes clearer in his proposal for a system of "quasi-judicial review."

\subsection{The System of Quasi-Judicial Review}

As argued, Conant was under no illusions regarding the value-neutrality of science. He was well aware that what he called "prejudice and opinion" play an inevitable role in the evaluation of research, especially in areas of science with direct implications for social and political life. He believed, however, that such prejudices are too often hidden behind a veil of technical language. In areas of research that are relevant for public policy-making, these hidden prejudices can pose dangers not only for the progress of science and technology, but to the broader public as well. As a result, he argued that such research should be organized so that prejudices can be identified, brought to light, and critically examined:

The notion that a scientist is a cool, impartial, detached individual is, of course, absurd. The vehemence of conviction, the pride of authorship burn as fiercely among scientists as among any creative workers. Indeed, if they did not, there would be no advance in science. But this emotional attachment to one's own point of view is particularly insidious in science because it is so easy for the proponent to clothe his convictions in technical language. Therefore it is necessary to explore ways and means of balancing the biases of experts whenever their opinions are of prime importance in the making of decisions. (Conant, 1952, p. 115)

Elsewhere, he laments the widespread illusion that, in technical matters:

there must be a right or wrong judgment and that it is rather indecent to have proponents present a clash of opinion and betray their prejudices.... The fact of the matter is that one cannot examine any proposal for future technical work without getting into an area in which prejudice and opinion are bound to have their influence. What I want to do is to have them come out in the open. (Quoted in Hershberg, 1993, p. 556)

This last comment provides some insight into why Conant believed that science is an intrinsically social enterprise. He argued that scientific research is shot through with values, but at the same time, he held that the operation of these values (or "prejudices") should not go 
unnoticed or unscrutizined. As a result, he argued that institutions that facilitate the scrutiny of such values are necessary for scientific and technological progress. ${ }^{12}$

Conant was concerned that the federal government, which was now a very significant player in scientific and technological research, did not have the requisite institutions to bring such prejudices out into the open. In particular, he was tremendously worried about the wisdom of projects undertaken by the Department of Defense (DoD), which he described as having a "fanatic enthusiasm for research and development" (Conant, 1952, p. 116). He worried that it too often pursued technological projects that were poorly conceived, cost inefficient, or unlikely to yield useable products. “The Department of Defense, in regard to research, is not unlike the man who sprang onto his horse and rode madly off in all directions” (Conant, 1952, p. 117).

The waste of money that results from poor decision-making, especially when the decisions involve extraordinary sums, presents an enormous burden on the taxpayer. More important for Conant, however, are the effects that poor decision-making could have in the Cold War:

The questions raised [concerning decision-making in the DoD] may serve to emphasize the extent to which every citizen in the United States is a party to an enormous new enterprise. His government has gone into the research and development business on a scale totally different from anything seen in the past.... Consequences of tremendous significance in terms of survival may hang on the way this work is carried on. The waste of enormous sums of money could threaten the soundness of our economy; failure to support adequately some areas, on the other hand, might result in our falling far behind in an armament race. The whole chain from pure science to the battlefield... is a responsibility of the representatives of the American electorate. Intelligent criticism and understanding public opinion are essential if all links in the chain are to operate effectively, particularly in periods of stress. (Conant, 1951, pp. 338-339, emphasis added)

This quotation makes clear Conant's belief that the outcome of the Cold War could very well depend upon the American government's ability to make good decisions with regard to scientific and technological development.

\footnotetext{
${ }^{12}$ In many respects, Conant's argument for the social character of science is similar to that found in Longino (1990; 2002). Longino argues that “contextual values” inevitably influence scientific reasoning and that these values must be subjected to critical scrutiny if the research in question is to be objective.
} 
Conant's solution to the problem of governmental decision-making in science and technology is what he called a system of "quasi-judicial review” (Conant, 1951, p. 338). ${ }^{13}$ The system would involve competing proposals for scientific and technological projects being debated before a panel of judges; briefs would then be written on behalf of opposing sides, and the judges would decide which side presented the stronger case. The participants in the debates were not supposed to be neutral, disinterested evaluators, but rather advocates for or against the proposal in question. By making proposals and counter-proposals, and by criticizing the grounds upon which an opponent was arguing, the assumptions and prejudices of each advocate would be brought to light. Conant described this process as follows:

The important point is that there should be arguments against the [DoD] proposal; they should be vigorous but candid; a technical expert should speak on behalf of the taxpayer against each large proposal. Then adequate briefs for the two sides could be prepared.... With opposing briefs, arguments, and cross-questioning, many facets of the problem, many prejudices of the witnesses would be brought out into the open. The forced opposition is the important point. (Conant, 1952, pp. 117-118)

In other words, Conant's solution to the problem of governmental decision-making in science and technology - and, more generally, to the problem of the value-ladenness of scientific inquiry - is a system of "forced opposition," or an institutional mechanism for ensuring organized skepticism. ${ }^{14}$

Conant's proposal is important and potentially very profitable, and it relates in interesting ways to the contemporary "science and values" debate. The system of quasijudicial review serves as institutional recognition that science is "shot through with values;" the institution itself is a repudiation of the belief that scientific research, especially research that is relevant for policy making, can be neutral or disinterested, as it demands that participants advocate for or against the proposal in question. Similarly, the system serves as an institutional acknowledgment of the social character of scientific research; legitimate

\footnotetext{
${ }^{13}$ Conant's system of quasi-judicial review is discussed briefly in Hamlin (2005).

${ }^{14}$ Organized skepticism is, of course, one of Merton's four norms of science (Merton, 1942). Conant does not, in his discussions of the system of quasi-judicial review, refer to Merton explicitly, but Conant's proposal is an interesting, and potentially very effective, way of institutionalizing Merton's norm.
} 
decisions are made not by individuals reasoning in an unbiased fashion but rather by scientists with definite interests working within a particular organizational structure. Conant's focus on the level of the group is similar to that of Longino (1990, 2002) and Solomon (2001) and different from that of Douglas (2009). Like Conant, Douglas rejects the ideal of value-free science, and she argues that scientists have a moral responsibility to consider the implications of their research, but her primary emphasis is upon the duties of individual scientists. Longino focuses upon the level of the community, and she emphasizes the need for communities to subject “contextual values” to critical scrutiny; unlike Conant, however, she does not provide an institutional mechanism for doing so. Finally, Conant's proposal is interesting for the essential role that it provides for dissent in science. Many writers, including Longino, place a higher value on consensus-seeking deliberation than on dissent, and they are optimistic about the ability of deliberative bodies to subject value-laden research to critical scrutiny. Conant is less sanguine in this regard and instead develops a proposal that institutionalizes dissent in science. In some respects, Conant's proposal is similar to Solomon's social empiricism, in that Solomon requires for scientific rationality an opposition of what she calls "non-empirical decision vectors;” unlike Conant, however, Solomon does not provide an institutional mechanism for achieving this. ${ }^{15}$

Conant did not elaborate in as much detail as he might have the way in which the system of quasi-judicial review was supposed to operate. For example, he said nothing about how the advocates for the two positions were to be chosen. In the case of a DoD proposal, while there would be little trouble in identifying competent advocates for the proposal, Conant provided no guidance regarding the choice of advocates for the opposing view. If this entire process were to take place within $\mathrm{DoD}$, what steps could be taken to ensure that the advocate

\footnotetext{
${ }^{15}$ Solomon distinguishes between empirical decision vectors, which are "causes of preference for theories with empirical success, either success in general or one success in particular," and non-empirical decision vectors, which are "other reasons or causes for choice," and she argues that empirical decision vectors should be distributed equitably and that non-empirical decision vectors should be distributed equally (Solomon, 2001, p. 56). Again, however, she provides no institutional mechanism for achieving such a distribution.
} 
against the proposal is truly competent and representative of the interests of the taxpayer? With regard to the choice of judges, Conant tentatively suggested that they need not be trained scientists or engineers: "Laymen who understand science and scientists and are familiar with engineering and engineers rather than technical experts might well prove the most suitable men for this task of refereeing technical disputes” (Conant, 1950, p. 202). Presumably, his reason for making this suggestion stemmed from his desire that the panel of judges not embody the same prejudices as one of the advocates. If the judges were trained in ways similar to one of the advocates - if, for example, they were trained within the same disciplines and, as a result, share a similar set of background assumptions or norms of reasoning - then there would be a danger that the judges would lean systematically toward one side of the debate. Choosing judges who are not scientists but have some familiarity with science and engineering could help to avoid such a problem.

Clearly, there are a number of difficulties that needed to be overcome before such a system could be established, and Conant left those difficulties for others to tackle. ${ }^{16}$ What is interesting for the purposes of this paper is the intimate connection between this organizational proposal and Conant's broader theory of science, including his epistemological holism and his rejection of the value-neutrality of science, and important place that this organizational proposal occupied within Conant’s strategic thinking about the Cold War.

\section{Conclusion}

This paper has examined James Conant’s pragmatic theory of science - a theory that has been neglected by most commentators on the history of $20^{\text {th }}$-century philosophy of science - and it has argued that this theory occupied an important place in Conant's strategic thinking about how the U.S. could achieve victory in the Cold War. By drawing upon his wartime

\footnotetext{
${ }^{16}$ Conant's proposal has been elaborated by others. It was a prototype for Arthur Kantrowitz's “science court” proposal (Kantrowitz 1967), and more recently, Biddle (2006, 2007) proposes it as a way of institutionalizing organized skepticism in the evaluation of pharmaceutical research.
} 
science policy work, his reading of the history of science, and Quine’s epistemological holism, Conant argued that there is no strict distinction between science and technology, that there is no such thing as "the scientific method," and that theories are better interpreted as policies rather than creeds. An important consequence that Conant drew from these arguments, especially from his epistemological holism, is that science is a thoroughly valueladen enterprise. This result, moreover, led him to view science as an intrinsically social enterprise and to develop novel proposals for organizing scientific research - proposals which he believed could help to win the Cold War.

The Cold War had a different impact upon Conant's thinking than it did upon many other theorists of science in America. While issues such as the role of science in society and the role of values in science were treated extensively by philosophers of science in the early $20^{\text {th }}$ century, these issues largely dropped off the philosophical agenda in the post-WWII years (Howard, 2003). The primary cause of this was the Cold War; during the Red Scare, it was safer for philosophers of science to focus upon more abstract, and less controversial, issues (Reisch, 2005). Interestingly, the Cold War did not affect Conant in this way. Conant developed a socially- and politically-engaged theory of science, but one that was explicitly in the service of the American Cold War effort. 


\section{References}

Biddle, J. (2006). Socializing science: On the epistemic significance of the institutional context of science. Ph.D. thesis, University of Notre Dame.

Biddle, J. (2007). "Lessons from the Vioxx debacle: What the privatization of science can teach us about social epistemology.” Social Epistemology 21(1): 21-39.

Boyd, R. (1983). “On the current status of scientific realism.” Erkenntnis 19:45-90.

Carnap, R., Hahn, H., \& Neurath, O. (1996 [1929]). The scientific conception of the world: The Vienna circle. In S. Sarkar (Ed.), The emergence of logical empiricism: From 1900 to the Vienna Circle (pp. 321-330). New York: Garland. (Translation of Wissenschaftliche Weltauffasung - der Wiener Kreis. Wien: Wolf, 1929.)

Conant, J. B. (1947). On understanding science: An historical approach. New Haven: Yale University Press.

Conant, J. B. (1950). Science and politics in the twentieth century. Foreign Affairs, 28(2), 189-202.

Conant, J. B. (1951). Science and common sense. New Haven: Yale University Press.

Conant, J. B. (1952). Modern science and modern man. New York: Columbia University Press.

Conant, J. B. (1967). Scientific principles and moral conduct. Cambridge: Cambridge University Press.

Conant, J. B. (1970). My several lives: Memoirs of a social inventor. New York: Harper \& Row.

Conant, J. B. (Ed.). (1957). Harvard case histories in experimental science. Cambridge, MA: Harvard University Press.

Dewey, J. (1929). The quest for certainty. New York: Minton, Balch \& Company.

Duhem, P. (1954 [1906]). The aim and structure of physical theory. Princeton: Princeton University Press. (Translation of La théorie physique: Son objet, sa structure. Paris: Marcel Rivière \& Cie, 1906.)

Frank, P. G. (1954). The variety of reasons for the acceptance of scientific theories. In Idem, The validation of scientific theories (pp. 3-17). Boston: Beacon Press.

Fuller, S. (2000). Thomas Kuhn: A philosophical history for our times. Chicago: University of Chicago Press.

Hamlin, C. (2005). A virtue-free science for public policy? Minerva, 43(4), 397-418.

Hershberg, J. (1993). James B. Conant: Harvard to Hiroshima and the making of the nuclear age. New York: Alfred A. Knopf. 
Howard, D. (2003). Two left turns make a right: On the curious political career of North American philosophy of science at midcentury. In G. Hardcastle, \& A. Richardson (Eds.), Logical empiricism in North America (pp. 25-93). Minneapolis: University of Minnesota Press.

Kantrowitz, A. (1967). “Proposal for an institution for scientific judgment.” Science 156(3776), 763-764.

Kevles, D. (1978). The physicists: The history of a scientific community in modern America. New York: Alfred A. Knopf.

Kuhn, T. S. (1962). The structure of scientific revolutions. Chicago: University of Chicago Press.

Laudan, L. (1981). A confutation of convergent realism. Philosophy of Science, 48(1), 19-49.

Longino, H. (1990). Science as social knowledge: Values and objectivity in scientific inquiry. Princeton: Princeton University Press.

Longino, H. (2002). The fate of knowledge. Princeton: Princeton University Press.

Merton, R. K. (1938). Science and the social order. Philosophy of Science, 5(3), 321-337.

Merton, R. K. (1942). A note on science and technology in a democratic order. Journal of Legal and Political Sociology, 1, 115-126.

McMullin, E. (1983). Values in science. In P. D. Asquith, \& T. Nickles (Eds.), PSA 1982, Vol.2 (pp. 3-28). East Lansing, Michigan: Philosophy of Science Association.

Nelson, J. (1996). The last dogma of empiricism? In L. H. Nelson, \& J. Nelson (Eds.), Feminism, science, and the philosophy of science, (pp. 59-78). Dordrecht: Kluwer.

Neurath, O. (1983 [1913]). The lost wanderers of Descartes and the auxiliary motive (on the psychology of decision). In R. S. Cohen, \& M. Neurath (Eds.), Philosophical Papers 19131946 (pp. 1-12). Dordrecht: Reidel. (Translation of Die Verirrten des Cartesius und das Auxiliarmotiv. Zur Psychologie des Entschlusses. Jahrbuch der Philosophischen Gesellschaft an der Universität Wien 1913 (pp. 45-59). Leipzig: Johann Ambrosius Barth).

Norton, B. (2011). Rejecting a third dogma of empiricism: Beyond separate discourses of fact and value. Unpublished manuscript.

Psillos, S. (1999). Scientific Realism: How Science Tracks Truth. London: Routledge.

Quine, W. V. O. (1951). Two dogmas of empiricism. Philosophical Review, 60(1), 20-43.

Quine, W. V. O., \& Ullian, J. S. (1970). The web of belief. New York: Random House.

Quine, W. V. O. (1986). Reply to Morton White. In L. E. Hahn, \& P. A. Schilpp (Eds.), The philosophy of W. V. O. Quine (pp. 663-665). Chicago: Open Court. 
Reisch, G. (2005). How the Cold War transformed philosophy of science: To the icy slopes of logic. Cambridge: Cambridge University Press.

Rudner, R. (1953). “The scientist qua scientist makes value judgments.” Philosophy of Science 20(1): 1-6.

Rhodes, R. (1986). The making of the atomic bomb. New York: Touchstone Books.

Slaney, P. (2005). Problems of scientific culture: The task of scientific education in the atomic age. M.A. thesis, University of Notre Dame.

Solomon, M. (2001). Social empiricism. Cambridge, MA: MIT Press.

van Fraassen, B. (2002). The empirical stance. New Haven: Yale University Press.

White, M. (1986). Normative ethics, normative epistemology, and Quine's holism. In L. E. Hahn, \& P. A. Schilpp (Eds.), The philosophy of W. V. O. Quine (pp. 649-662). Chicago: Open Court.

Zachary, P. G. (1997). Endless frontier: Vannevar Bush, engineer of the American century. New York: The Free Press. 